\title{
Burden and quality of life in caregivers of persons with multiple sclerosis
}

\section{Obciążenie i jakość życia opiekunów osób chorych na stwardnienie rozsiane}

\author{
Józef Opara', Krystyna Jaracz², Waldemar Brola ${ }^{3}$ \\ 1 Katedra Fizjoterapii Układu Nerwowego i Narzq̨du Ruchu, Akademia Wychowania Fizycznego im. J. Kukuczki w Katowicach \\ 2Zakład Pielęgniarstwa Neurologicznego i Psychiatrycznego, Uniwersytet Medyczny im. K. Marcinkowskiego w Poznaniu \\ 30ddział Neurologiczny, Szpital Specjalistyczny im. św. tukasza w Końskich
}

Neurologia i Neurochirurgia Polska 2012; 46, 5: $472-479$

DOI: 10.5114/ninp.2012.31358

\begin{abstract}
Multiple sclerosis (MS) is the second most common cause of disability among nervous system diseases. This disease causes reduced quality of life of patients and those caring for them. Quality of life (QoL) measures consist of at least three broad domains: physical, mental and social. In the field of medicine, researchers have often used the concept of health-related quality of life, which specifically focuses on the impact of an illness and/or treatment on patients' perception of their status of health and on subjective well-being or satisfaction with life. Subjective factors of QoL in MS patients include perception of symptoms, level of fitness, self-image, satisfaction with family life, work, the economic situation, interaction with other people, social support and life in general. Objective factors include the clinical picture of disease, social status, social and living conditions and the number and intensity of social contacts. While many generic and specific questionnaires have been developed to assess QoL in patients with MS, including general fatigue, there is a lack of specific questionnaires assessing QoL of caregivers.

In this paper, a review of selected studies on QoL and caregiver burden in MS and a summary of the most popular questionnaires measuring burden and $\mathrm{QoL}$ are presented. Special attention is paid to the first questionnaire specific for QoL of carers of persons with MS, CAREQOL-MS by Benito-León et al.
\end{abstract}

Key words: multiple sclerosis, quality of life, caregiver burden.

\section{Streszczenie}

Stwardnienie rozsiane jest drugą najczęstszą przyczyną niepełnosprawności spośród chorób układu nerwowego. Choroba ta powoduje obniżenie jakości życia chorych i osób opiekujących się nimi. Ocena jakości życia składa się co najmniej z trzech głównych wymiarów: fizycznego, psychicznego i społecznego. W dziedzinie medycyny naukowcy często używają koncepcji jakości życia, która skupia się przede wszystkim na wpływie choroby i/lub leczenia pacjentów na postrzeganie ich ogólnego stanu zdrowia, subiektywnego dobrostanu i satysfakcji z życia.

Do czynników subiektywnych jakości życia u chorych na stwardnienie rozsiane należą: postrzeganie objawów i poziomu sprawności, obraz samego siebie, zadowolenie z życia rodzinnego, pracy, sytuacji finansowej, interakcji z innymi ludźmi, wsparcia społecznego i z życia w ogóle. Do czynników obiektywnych zalicza się: obraz kliniczny choroby, status społeczny, warunki życia oraz liczbę i intensywność kontaktów międzyludzkich. Opracowano wiele ogólnych i szczegółowych kwestionariuszy służących do oceny jakości życia chorych na stwardnienie rozsiane, nie ma natomiast specyficznych narzędzi do oceny jakości życia i obciążenia opieką opiekunów osób chorych.

W niniejszym artykule przedstawiono przegląd wybranych badań dotyczących jakości życia i obciążenia w stwardnieniu rozsianym, jak również zaprezentowano najbardziej popularne kwestionariusze służące do oceny jakości życia chorych

Correspondence address: Prof. Józef Opara, Akademia Wychowania Fizycznego im. J. Kukuczki w Katowicach, ul. Mikołowska 72b, 40-065 Katowice, e-mail: jozefopara@wp.pl

Received: 26.09.2011; accepted: 16.03.2012 


\section{Introduction}

Multiple sclerosis (MS) is the second most common cause of disability among nervous system diseases, next to stroke and before Parkinson's disease. The Polish statistical yearbook issued in 2006 shows that in 2004 in Poland there were 96,700 MS patients, of whom twothirds $(64,300)$ were persons with disability [1]. This disease is the cause of reduced quality of life of patients and those caring for them. While many generic and specific questionnaires have been developed to assess quality of life in patients with MS, including general fatigue, specific questionnaires assessing quality of life of caregivers are lacking.

\section{Quality of life in multiple sclerosis}

Quality of life (QoL) measures consist of at least three broad domains: physical, mental and social. In the field of medicine, researchers have often used the concept of health-related quality of life, which specifically focuses on the impact of an illness and/or treatment on patients' perception of their status of health and on subjective well-being or satisfaction with life [2]. QoL is considered to be suitable for the outcome measure of a new treatment and rehabilitation [3]. Subjective factors of QoL in MS patients include perception of symptoms, level of fitness, self-image, satisfaction with family life, work, the economic situation, interaction with other people, social support and life in general. Objective factors of QoL include the clinical picture of disease, social status, social and living conditions and the number and intensity of social contacts. The scales used to assess the QoL in MS include either subjective or objective indicators, or both, and can be divided into universal (general, generic) and specific for the disease (disease-oriented) $[2,3]$. In our review of QoL measures, we included, as well as questionnaires generic and specific for MS, evaluation of cognitive functions and depression, global fatigue, evaluation of functional state, and QoL in visual disturbances in MS, to assess the role na stwardnienie rozsiane i ich opiekunów. Szczególną uwagę zwrócono na pierwszą skalę specyficzną dla oceny jakości życia opiekunów osób chorych na stwardnienie rozsiane CAREQOL-MS, skonstruowaną przez Benito-Leóna i wsp.

Słowa kluczowe: stwardnienie rozsiane, jakość życia, obciążenie opieką.

of comorbidity [3]. The first author in his review article in 2005 stated that assessment of quality of life was useful for evaluating the results of rehabilitation in MS [4].

Benedict et al. [5] stated in 2005 that health-related QoL (HRQoL) was poor in MS but the clinical precipitants of the problem were not well understood. They measured HRQoL (MS Quality of Life-54) and vocational status in $120 \mathrm{MS}$ patients and concluded that selfreported HRQoL indices were most strongly predicted by measures of depression, whereas vocational status is predicted primarily by objective measures of cognitive function.

Benito-León et al. [6] stated in 2002 that worse cognitive functioning and higher depressive and anxiety symptoms score were associated with lower HRQoL in MS [6]. Many authors have proved that depression can lower HRQoL in MS [7].

Cella et al. [8] developed a quality of life instrument for use with people with MS, called the Functional Assessment of Multiple Sclerosis (FAMS). Fischer et al. [9] compared the MSQLI (Multiple Sclerosis Quality of Life Inventory) with two other MS-specific HRQoL measures - MS Quality of Life-54 (QOL-54) and FAMS - and discussed key issues to consider in selecting an HRQoL instrument for a collaborative database [9].

Isaksson et al. [10] concluded that a self-reported impairment checklist and SF-36 proved to be valuable complements to the well-established Expanded Disability Status Scale (EDSS) in describing the diverse symptoms of MS. Measuring both HRQoL and subjective wellbeing provides valuable knowledge about the consequences of MS. Kurtzke's EDSS is still a widely used method of quantifying ambulation in MS [11]. Lobetanz et al. [12] after assessment of 504 patients stated that disability status, fatigue and reduced sleep quality had an impact mainly on physical domains of QoL. Miller and Dishon assessed the HRQoL of 215 MS outpatients using the MSQOL-54 and Fatigue Severity Scale (FSS), and that of 172 healthy controls, using the SF-36 (a subset of MSQOL-54). They concluded that multiple attributes, including disability, gen- 
der and employment status, affected QoL. The relationship between QoL and disability is complex, displaying non-linearity and interacting with patient characteristics [13]. Dworzańska et al. [14] stated that fatigue was associated with reduced QoL in MS. Mitchel et al. stated that traditional medical models of impairment and disability were an incomplete summary of disease burden. QoL can be thought of as the sum of all sources of satisfaction (including anticipated sources) minus all threats (including anticipated threats). Many psychosocial factors, including coping, mood, self-efficacy, and perceived support, influence the QoL of patients with MS more than biological variables such as weakness or extent of magnetic resonance imaging (MRI) lesions. Subjective (self-report) HRQoL measures may serve to alert clinicians to areas that would otherwise be overlooked. Studies of new interventions should include an assessment of HRQoL, not just impairment or disability alone [15].

Mowry et al. [16] performed a cross-sectional baseline analysis of 507 patients with MS in a prospective cohort study and concluded that aspects of HRQoL in MS were associated with MRI evidence of white matter lesions and brain atrophy.

Twork et al. [17] sent a questionnaire containing Multiple Sclerosis Quality of Life (MSQOL-54) and an assessment of self-reported disability status analogous to the EDSS to $7305 \mathrm{MS}$ patients, and finally 3157 patients participated in the study. Patients were allocated to three groups according to disability status. Regarding the physical health composite and the mental health composite as well as most MSQOL-54 subscales, the differences between EDSS 4.5-6.5 and EDSS $>$ or $=7$ were clearly smaller than the differences between EDSS $<$ or $=4$ and EDSS 4.5-6.5. These findings indicate a non-linear relationship between disability status and HRQoL in MS. The EDSS does not seem to be interval-scaled as is commonly assumed. Consequently, an absolute increase in EDSS does not seem to be a suitable outcome variable in MS studies [17].

Visschedijk et al. [18] collected for over a 5-year period data on HRQoL (Medical Outcomes Study Short Form-36 Health Survey) and disability status (EDSS) from a heterogeneous group of 81 Dutch-speaking patients with MS. They concluded that a patient's subjectively perceived health-related quality of life might not be only a clinically and psychosocially meaningful outcome per se but might also be a predictor of objective outcomes such as change in disability status over a substantial period of time.
Vickrey et al. [19] evaluated the relative contributions of generic and disease-targeted measures to the assessment of HRQoL in MS. They administered a generic HRQoL measure, Short Form-36 (SF-36), three disease-targeted supplemental scales to the SF-36, and two disease-targeted HRQoL instruments to 171 adults with MS. The disease-targeted scales provided unique information not captured by the generic measure. The authors concluded that if a generic measure of HRQoL is desirable for a given study of MS, additional information will be gained by supplementing that measure with selected scales [19].

Gold et al. [20] developed a new questionnaire the Hamburg Quality of Life Questionnaire in Multiple Sclerosis (HAQUAMS). Hobart et al. [21] developed the Multiple Sclerosis Impact Scale (MSIS-29) a new patient-based outcome measure in MS. JamrozWiśniewska et al. [22] adapted and validated the Polish version of MSIS-29.

In our two reports published in 2008 and 2010, we stated that the Visual Function Questionnaire (VFQ-25) was a valuable tool for investigation of the effect of visual disturbances on QoL in MS patients [23,24].

\section{Burden and quality of life of caregivers}

There are many different definitions of caregiver burden in the literature. This term is frequently used as a synonym of caregiver strain or stress. Pearlin et al. [25] described burden as the impact that care has on mental and physical health, on family relations, on work activity and the financial situation of a caregiver. The care is usually provided by a close family member, often a spouse or a child, usually a daughter who lives with the patient. Carers provide assistance with basic personal hygiene and daily activities, provide emotional support, arrange for medical services and social assistance. As a result, they may experience high levels of chronic stress that can lead to deterioration of the carers' health status, social life and well-being.

Caring for MS patients, as has been shown in the literature, may negatively impact several objective and subjective aspects of a caregiver's life, such as physical and emotional health, morale, work life, finances, social mobility, interpersonal relationships and sexual life. Studies on psychological consequences of caregiving reported that the perceived caregiver burden is significantly correlated with higher risk for depression, anxiety and lower QoL for caregivers [26]. 
The severity of burden perceived by carers depends on a variety of factors, from the side of both caregivers and patients. They may be summarized as follows: (1) factors from a patient's side: low functional status, the presence of depression, the presence of behavioral and cognitive disturbances, being male, older age; (2) factors from a caregiver's side: older age, being female, not being employed, being the care receiver's daughter-inlaw, amount of surveillance time, the presence of depression, the presence of disability, sense of coherence, and non-informal social support of the caregiver [27-31].

There is an abundance of research on negative consequences of the caregiving role. It is worth highlighting, however, that caregivers not only perceive burden, but also may experience positive emotions such as satisfaction, pride, gratification and feeling closer to their partners [32]. Nevertheless, studies about negative consequences still account for the majority of research on informal caregiving.

Buhse [33] wrote that family members of people with MS often became caregivers, adding to the demands and challenges of family life. As the disease progresses, the capacity for self-care may decrease, and the individual may require temporary or continual daily assistance. However, the daily assistance that family members provide to a disabled spouse, parent, partner, or child can take a physical and economic toll on the caregiver, causing long-term caregiver burden and a higher risk of depression and thus in the author's opinion early recognition of burden is important in determining appropriate interventions.

In Akkuş's [34] study, 49 caregivers of persons with MS were assessed using the Zarit Caregiver Burden Interview (ZCBI). Most of the caregivers (63.3\%) were female and patients' spouses (55\%). The majority of them were involved in bathing (59\%) and dressing (55\%) activities. A significant correlation was found between the ZCBI score and dimensions of the Psychological and the Social Needs Scale (hopelessness, conflict in decision making, leisure activity deficit and social isolation). The following variables were associated with an increase of the ZCBI scores: insufficient income, unemployment, presence of chronic disease, financial problems, difficulties in maintaining responsibilities, caregiver responsibilities involving dressing and positioning of the patient.

In a recent report by Argyriou et al. [35], a sample of 22 male and 13 female primary caregivers (mean age, 47 years) and an equal number of patients with MS were described. Caregivers experienced a higher degree of anxiety than depression. Highly educated caregivers were more prone to increased levels of anxiety and depression than poorly educated subjects. The authors concluded that the caregivers were psychologically burdened to a significant degree that consequently deteriorated their QoL. In another report, Argyriou et al. [36] described deterioration of quality of sleep in the same study group using the Pittsburgh Sleep Quality Index (PSQI). PSQI scoring demonstrated that 54\% of caregivers had poor sleep quality. The mean value of caregivers in the PSQI was $6.0 \pm 2.8$ (range, 2-12), while controls scored significantly lower $(1.5 \pm 0.8 ; p<0.001)$. Poor quality of sleep was significantly correlated with increased levels of anxiety $(r=0.392 ; p=0.02)$ and depression $(r=0.424 ; p=0.01)$. Among the PSQI components, sleep duration and sleep latency were the most influenced by the degree of emotional distress. The authors concluded that a significant proportion of primary caregivers of MS patients experience poor sleep quality, which in turn may negatively impact their QoL.

Aronson [37] conducted a large survey of persons with MS and their caregivers in Ontario, Canada using self-completed mailed questionnaires. The study objectives included describing satisfaction with $\mathrm{QoL}$ and determining relationships between $\mathrm{QoL}$ as a whole and several factors, such as demographic characteristics and measures of physical disability of the patients. Among 697 respondents with MS, 70\% were women, and 75\% were married, with a mean age of 48 years. While $24 \%$ experienced no mobility restrictions, the majority required some type of aid or a wheelchair for getting around. Health received the lowest satisfaction rating among the six components of QoL, while finances received a relatively low satisfaction rating from the 345 caregivers. Less satisfaction with several QoL components was evident for those with MS compared with the disabled in the Canadian general population, and for caregivers compared with the able-bodied general population. Poorer QoL as a whole among those with MS was associated with unemployment, MS symptoms of moderate or worse, fatigue, mobility limitations on stairs, and a disease course other than stable, and was most strongly related to interference by MS in social activities. Among caregivers, poorer QoL was associated with being a spouse, longer duration of caregiving, and moderate or worse MS symptoms in the care recipient, and most strongly related to a care recipient's current MS disease course of other than stable. The author stated that through an understanding of the satisfaction with QoL of persons with MS and caregivers, and the rela- 
tionships with other key factors, autonomy and home care might be supported and prolonged, while preventing unnecessary institutionalization [37].

Buchanan et al. [29] collected data from a national survey of informal caregivers and analyzed characteristics associated with burden among male caregivers. Greater burden among caregivers was associated with significantly more hours per week providing assistance $(p=0.009)$ and significantly greater restriction on the caregiver's ability to perform daily activities $(p<0.001)$ due to assisting the person with MS. They found a strong association between the perception of burden and the mental health status of the caregivers $(p<0.001)$. The authors concluded that those findings highlighted the strong association of caregiver burden and the Mental Component Summary of the SF-8, which may indicate that reducing burden can improve the mental health of the caregivers. They also stated that health professionals treating either male caregivers or people with MS should be sensitive to the impact that providing assistance has on the mental health of informal caregivers.

Finlayson and Cho [38] presented a descriptive profile of caregivers of older adults with MS and the assistance they provided. The purpose of their telephone interview was to compare 302 spousal and non-spousal caregivers of older adults with MS, and to characterize the nature and extent of assistance they provided, as well as the challenges they experienced in the course of their caregiving role. Spousal and non-spousal caregivers differed in age, sex, location of residence, and employment status. Spousal caregivers assisted with more activities, although non-spousal caregivers provided equivalent caregiving time. Twenty percent of caregivers spent more than 3.5 hours per day caregiving. Caregiving time was influenced by cognitive and ADL (activities of daily living) status of the person with MS, and the number of caregiving activities performed. Challenges reported by caregivers in both groups were similar. The authors concluded that both spousal and non-spousal caregivers of older adults with MS provided substantial assistance, and experienced many challenges. Rehabilitation professionals need to be aware of the diversity of caregivers and the assistance they provide to facilitate appropriate support and resources.

Jaracz et al. [39] evaluated 210 MS patients (150 women) aged between 21 and 59 years. They stated that MS influenced QoL but to a greater extent in the physical than the psychological domain. The role of social support measured by the Social Provisions Scale (SPS) in QoL was generally positive but its protective function might be weakened when interacting with other factors. Depression was found to be the main predictor of $\mathrm{QoL}$ when adjusted for other factors. Thus, treatment of mood disturbances might significantly improve QoL in MS patients.

Khan et al. [27] made a cross-sectional survey of 62 informal caregivers and 101 participants with confirmed MS and quantified physical and cognitive disability. The mean caregiver age was 54 years (range, 37-62). The mean caregiver strain score according to the Caregiver Strain Index was 5.63 (standard deviation, 3.63) (total score, 0-13). Forty-two percent of caregivers reported strain for items such as emotional adjustments, demands on time, change in personal plan and disrupted sleep. Caregiver burden was higher in those caring for the more severely affected persons with MS, especially those with higher depression, anxiety and stress levels. The caregiver strain correlated with a lower QoL both in the persons with MS and their caregivers, but not with their self-efficacy scores.

Patti et al. [40] evaluated 445 Italian patients with definite MS and 445 of their caregivers using the 36-item short-form (SF-36) Health Survey. Median SF-36 dimension scores ranged from 55 to 100 for caregivers and from 46 to 78 for patients. Although the $\mathrm{QoL}$ of MS carers was not as severely affected as that of patients, caregiving was associated with lower mental health, vitality and general health scores compared to healthy subjects. Multivariate analyses revealed significant differences between the predictors of patient QoL and caregiver $\mathrm{QoL}$. The main predictors of patient $\mathrm{QoL}$ were EDSS score, MS course, fatigue and depression. Female gender and advanced age were the main predictors of lower QoL in caregivers. In addition, patient emotional status measured with the Beck Depression Inventory was found to be a significant predictor of almost all caregiver SF-36 dimension scores, while EDSS score, disease duration and course, and patient therapeutic characteristics were found to be predictors of some caregiver SF-36 dimensions.

Rivera-Navarro et al. [30] studied 278 caregivers of persons with MS, recruited from a Spanish crosssectional survey, measuring health-related quality of life by the SF-36 and burden by the ZCBI. Of the caregivers, $56.8 \%$ were female and their mean age was 50.1 (standard deviation, 12.6) years. Their main relationship with the person with MS was spouse/partner (52.9\%) and son or daughter (25.9\%). Caregiver General Health, Mental Health, Bodily Pain, and Role-emotional Functioning were the most affected dimensions on the SF-36. Multiple regression analysis showed that independent and signifi- 
cant predictors of burden were Role-emotional Functioning and Vitality dimensions SF-36 scores of caregivers, and the EDSS scores. The total adjusted variance explained by these variables (adjusted $\mathrm{R}^{2}$ ) was 0.512 . Emotional factors and the disability of the person with MS were major predictors of burden.

In the study by Waldron-Perrine et al. [41], there were 64 caregivers of patients with MS and the patients for whom they cared. Multiple regression analysis indicated that caregiver perception of illness uncertainty and patients' unawareness of deficits had unique value in predicting caregiver life satisfaction, even after accounting for general financial status. Gender and level of social support were also important contributing factors to caregiver life satisfaction. These findings suggest that duration and severity of the patients' illness take a greater toll on life satisfaction of caregivers with low versus high social support, particularly among women caregivers.

This review demonstrates that the QoL reduction and burden among persons caring for MS patients is significant and that the burden is influenced by several factors, some of which are modifiable. This means that there is room for professional interventions to reduce caregivers' strain and as a result to improve their QoL. Grabowska-Fudala and Jaracz stated that, as for stroke, the caregiver's burden was determined mainly by caregiver's internal factors but not with the external factors such as a social support [42].

The most commonly used generic questionnaires assessing quality of life and burden of carers in MS are: Burden Interview (BI index), Caregiver Burden Scale (CBS), Caregiver Reaction Assessment (CRA), Caregiver Strain Index (CS), Life Situation Questionnaire (LSQ) and the Sense of Competence Questionnaire (SCQ) $[2,43]$. The 26-item WHOQOL-Bref, SF-36 and the ZCBI are also utilized. The latter is one of the most popular measures among tools evaluating caregiver burden. It consists of 22 items assessing the extent to which caregivers view their responsibilities as having an adverse impact on their social life, health, emotional well-being, and finances. The range of scoring is from "never" (0 points) to "almost always" (score 4$)$. The total sum is from 0 to 88 , with higher totals reflecting greater burden [43].

\section{Quality of life of caregivers of MS patients - first specific questionnaire}

In 2011, Benito-León et al. [44] published the first specific questionnaire for assessing the $\mathrm{QoL}$ of carers of patients with MS: Caregiver Health-Related Quality of Life in Multiple Sclerosis (CAREQOL-MS). It consists of 24 items comprising four subscales: physical stress/global health, social integration, emotion, and the need for assistance/emotional reactions. Questionnaire items were derived from a literature review and the views of patients, caregivers, and experts. They are scored on a 5-point Likert-type scale (higher scores reflecting worse HRQoL).

A high correlation was found between the sub-scales of CAREQOL-MS and the above-mentioned ZCBI scale and a moderate correlation was noted with the SF-36 scale. A significant correlation was observed between the CAREQOL-MS score and carers' age and patients' EDSS scores. The average standard error for the subscales ranged from 2.01 to 2.43. The scale was free of floor or ceiling effects. For subscales, Cronbach's alpha coefficient ranged from 0.80 to 0.90 . These results gave evidence for the usefulness and satisfactory psychometric properties of the questionnaire CAREQOL-MS [44] (see Appendix).

\section{Disclosure}

Authors report no conflict of interest.

\section{References}

1. Główny Urząd Statystyczny. Stan zdrowia ludności Polski w 2004 r. http://www.stat.gov.pl/gus/5840_658_PLK_HTML.htm.

2. Opara J., Jaracz K., Brola W. Quality of life in multiple sclerosis. J Med Life 2010; 3: 352-358.

3. Opara J., Jaracz K., Brola W. Aktualne możliwości oceny jakości życia w stwardnieniu rozsianym. Neurol Neurochir Pol 2006; 40: 336-341.

4. Opara J. Klinimetria w stwardnieniu rozsianym. Post Psychiatr Neurol 2005; 3: 219-226.

5. Benedict R.H., Wahling E., Bakshi R., et al. Predicting quality of life in multiple sclerosis: accounting for physical disability, fatigue, cognition, mood disorder, personality, and behavior change. J Neurol Sci 2005; 321: 29-34.

6. Benito-León J., Morales J.M., Rivera-Navarros J. Health-related quality of life and its relationship to cognitive and emotional functioning in multiple sclerosis patients. Eur J Neurol 2002; 9: 497-502.

7. Potemkowski A. (red.). Psychologiczne aspekty stwardnienia rozsianego. Termedia, Poznań 2010.

8. Cella D.F., Dineen K., Arnason B., et al. Validation of the functional assessment of multiple sclerosis quality of life instrument. Neurology 1996; 47: 129-139.

9. Fischer J.S., la Rocca N.G., Miller D.M., et al. Recent development of quality of life in multiple sclerosis (MS). Mult Scler 1999; 5: 251-259. 
10. Isaksson A.K., Ahlstrom G., Gunnarsson L.G. Quality of life and impairment in patients with multiple sclerosis. $J$ Neurol Neurosurg Psychiatry 2005; 76: 64-69.

11. Kurtzke J.F. Rating neurologic impairment in multiple sclerosis: an expanded disability status scale (EDSS). Neurology 1983; 33: 1444-1452.

12. Lobentanz I.S., Asenbaum S., Vass K. Factors influencing quality of life in multiple sclerosis patients: disability, depressive mood, fatigue and sleep quality. Acta Neurol Scand 2004; 110: 6-13.

13. Miller A., Dishon S. Health-related quality of life in multiple sclerosis: psychometric analysis of inventories. Mult Scler 2005; 11: 450-458

14. Dworzańska E., Mitosek-Szewczyk K., Stelmasiak Z. Zespół zmęczenia w stwardnieniu rozsianym. Neurol Neurochir Pol 2009; 43: 71-76.

15. Mitchell A.J., Benito-Leon J., Rivera-Navarro J. Quality of life and its assessment in multiple sclerosis: integrating physical and psychological components of wellbeing. Lancet Neurol 2005; 4: 556-566.

16. Mowry E.M., Beheshtian A., Waubant E., et al. Quality of life in multiple sclerosis is associated with lesion burden and brain volume measures. Neurology 2009; 72: 1760-1765.

17. Twork S., Wiesmeth S., Spindler M., et al. Disability status and quality of life in multiple sclerosis: non-linearity of the Expanded Disability Status Scale (EDSS). Health Qual Life Outcomes 2010; 7: 55-60.

18. Visschedijk M.A., Uitdehaag B.M., Klein M., et al. Value of health-related quality of life to predict disability course in multiple sclerosis. Neurology 2004; 63: 2046-2050.

19. Vickrey B.G., Hays R.D., Genovese B.J., et al. Comparison of a generic to disease-targeted health-related quality-of-life measures for multiple sclerosis. J Clin Epidemiol 1997; 50: 557-569.

20. Gold S.M., Heesen C., Schultz H., et al. Disease specific quality of life instruments in multiple sclerosis: validation of the Hamburg Quality of Life Questionnaire in Multiple Sclerosis (HAQUAMS). Mult Scler 2001; 7: 119-130.

21. Hobart J., Lamping D., Fitzpatrick R., et al. The Multiple Sclerosis Impact Scale (MSIS -29): a new patient-based outcome measure. Brain 2001; 124: 962-973.

22. Jamroz-Wiśniewska A., Papuć E., Bartosik-Psujek H., et al. Validation of selected aspects of psychometry of the Polish version of the Multiple Sclerosis Impact Scale 29 (MSIS-29). Neurol Neurochir Pol 2007; 41: 215-222.

23. Opara J.A., Szwejkowski W., Brola W. Jakość życia w zaburzeniach widzenia w stwardnieniu rozsianym. Wiad Lek 2008; 61: 67-71.

24. Brola W., Opara J., Fudala M., et al. Polska adaptacja i analiza walidacyjna Kwestionariusza Funkcji Wzrokowych (Visual Function Questionnaire VFQ-25) u chorych ze stwardnieniem rozsianym. Wiad Lek 2010; 63: 161-170.

25. Pearlin L.I., Mullan J.T., Semple S.J., et al. Caregiving and the stress process: an overview of concepts and their measures. Gerontologist 1990; 30: 583-594.

26. Kouzoupis A.B., Paparrigopoulos T., Soldatos M., et al. The family of the multiple sclerosis patient: a psychosocial perspective. Int Rev Psychiatr 2010; 22: 83-89.
27. Khan F., Pallant J., Brand C. Caregiver strain and factors associated with caregiver self-efficacy and quality of life in a community cohort with multiple sclerosis. Disabil Rehabil 2007; 29: 1241-1250.

28. Figved N., Myhr K.M., Larsen J.P., et al. Caregiver burden in multiple sclerosis: the impact of neuropsychiatric symptoms. J Neurol Neurosurg Psychiatry 2007; 78: 1097-1102.

29. Buchanan R.J., Radin D., Huang C. Caregiver burden among informal caregivers assisting people with multiple sclerosis. Int J MS Care 2011; 13: 76-83.

30. Rivera-Navarro J., Benito-León J., Oreja-Guevara C., et al. Caregiver Quality of Life in Multiple Sclerosis (CAREQOL-MS) Study Group. Burden and health-related quality of life of Spanish caregivers of persons with multiple sclerosis. Mult Scler 2009; 15: 1347-1355.

31. Knight R.G., Devereux R.C., Godfrey H.P. Psychosocial consequences of caring for a spouse with multiple sclerosis. $J$ Clin Exp Neuropsychol 1997; 19: 7-19.

32. Rees J., O'Boyle C., MacDonagh R. Quality of life: impact of chronic illness on the partner. $J R$ Soc Med 2001; 94: 563-566.

33. Buhse M. Assessment of caregiver burden in families of persons with multiple sclerosis. J Neurosci Nurs 2008; 40: 25-31.

34. Akkus Y. Multiple sclerosis patient caregivers: the relationship between their psychological and social needs and burden levels. Disabil Rehabil 2011; 33: 326-333.

35. Argyriou A.A., Karanasios P., Ifanti A.A., et al. Quality of life and emotional burden of primary caregivers: a case-control study of multiple sclerosis patients in Greece. Qual Life Res 2011; 20: 1663-1668.

36. Argyriou A.A., Karanasios P., Assimakopoulos K., et al. Assessing the quality of sleep in Greek primary caregivers of patients with secondary progressive multiple sclerosis: a cross-sectional study. J Pain Symptom Manage 2011; 42: 541-547.

37. Aronson K.J. Quality of life among persons with multiple sclerosis and their caregivers. Neurology 1997; 48: 74-80.

38. Finlayson M., Cho C.A. Descriptive profile of caregivers of older adults with MS and the assistance they provide. Disabil Rehabil 2008; 30: 1848-1857.

39. Jaracz K., Pawlak M., Górna K., et al. Quality of life and social support in patients with multiple sclerosis. Neurol Neurochir Pol 2010; 44: 358-365.

40. Patti F., Amato M.P., Battaglia M.A., et al. Caregiver quality of life in multiple sclerosis: a multicentre Italian Study. Mult Scler 2007; 13: 412-419.

41. Waldron-Perrine B., Rapport L.J., Ryan K.A., et al. Predictors of life satisfaction among caregivers of individuals with multiple sclerosis. Clin Neuropsychol 2009; 23: 462-478.

42. Grabowska-Fudala B., Jaracz K. Obciążenie osób sprawujących opiekę nad chorymi po przebytym udarze mózgu. Udar Mózgu. Problemy Interdyscyplinarne 2006; 8: 42-47.

43. Zarit S.H., Reever K.E., Bach-Peterson J. Relatives of the impaired elderly: correlates of feelings of burden. Gerontologist 1980; 20: 649-655.

44. Benito-León J., Rivera-Navarro J., Guerrero A.L.; Caregiver Quality of Life In Multiple Sclerosis (CAREQOL-MS) Study Group: The CAREQOL-MS was a useful instrument to measure caregiver quality of life in multiple sclerosis. J Clin Epidemiol 2011; 64: 675-686. 


\section{Appendix}

\begin{tabular}{|c|c|}
\hline Caregiver & r health-related quality of life (HRQOL) in Multiple Sclerosis - CAREQOL-MS Questionnaire* \\
\hline 1. I & I worry about the thoughts regarding multiple sclerosis of the person whom I care for. \\
\hline 2. I & I reflect about the suffering the limited mobility brings to the person with multiple sclerosis whom I care for. \\
\hline 3. $\mathrm{N}$ & Moving and traveling with the person with multiple sclerosis whom I care for is complicated for me. \\
\hline 4. I & [ worry about the fatigue of the person with multiple sclerosis whom I care for. \\
\hline 5. $\mathrm{T}$ & The fatigue of the person with multiple sclerosis whom I care for poses a greater physical burden to me. \\
\hline 6. $\mathrm{T}$ & The personal hygiene of the person with multiple sclerosis whom I care for proves complicated. \\
\hline 7. I & feel alone regarding my tasks of caring for, watching, and supporting a person with multiple sclerosis. \\
\hline 8. I & believe that my situation might improve through the collaboration of other caregivers. \\
\hline 9. $\mathrm{C}$ & Caring for a person with multiple sclerosis leaves me with no time for caring for the rest of my family. \\
\hline 10. $\mathrm{N}$ & Multiple sclerosis has affected my social life. \\
\hline 11. $\mathrm{T}$ & Taking care of a person with multiple sclerosis has meant a change in my lifestyle. \\
\hline 12. I & $\begin{array}{l}\text { miss the company of persons outside the family circle who are acquainted with the disease, so I can share my current } \\
\text { ituation with them. }\end{array}$ \\
\hline 13. $\mathrm{T}$ & The attitude of the person with multiple sclerosis whom I care for elicits mood changes in me. \\
\hline 14. $\mathrm{T}$ & The nervousness of the person with multiple sclerosis whom I care for irritates me. \\
\hline 15. I & feel sad as a consequence of the multiple sclerosis of the person whom I care for. \\
\hline 16. $\mathrm{N}$ & Multiple sclerosis has affected my relationship with my partner, either regarding our sexual or emotional relationship. \\
\hline 17. I & I believe that some psychological aid would help me provide better care for the person with multiple sclerosis. \\
\hline 18. I & $\begin{array}{l}\text { have been suffering from sleep disturbances since I learned that the person whom I care for suffers from } \\
\text { nultiple sclerosis. }\end{array}$ \\
\hline 19. $\mathrm{T}$ & The evening care of the person with multiple sclerosis whom I care for prevents me from resting at night. \\
\hline 20. I & I am scared about the progress and the consequences of multiple sclerosis. \\
\hline 21. M & My own health has worsened over the course of this year. \\
\hline $\begin{array}{l}\text { 22. } \\
\text { ap }\end{array}$ & $\begin{array}{l}\text { Ever since the person whom I care for started suffering from multiple sclerosis, I devote less time to my own personal } \\
\text { appearance and wellbeing. }\end{array}$ \\
\hline 23. $\mathrm{T}$ & The care of the person with multiple sclerosis has affected my work life. \\
\hline 24. $\mathrm{T}$ & 年 \\
\hline
\end{tabular}

*reproduced from Benito-León et al. [44], with permission 